\title{
HUBUNGAN PENGETAHUAN DAN PERSEPSI TENTANG MASALAH KESEHATAN KERJA DAN PERILAKU PENGGUNAAN ALAT PELINDUNG DIRI PETANI TEMBAKAU
}

\author{
Megah Andriany ${ }^{1}$, Kusyogo Cahyo $^{2}$, Aditya Kusumawati ${ }^{3}$ \\ ${ }^{1}$ Dosen Divisi Keperawatan Dewasa, Sub Divisi Keperawatan Emergensi dan Kritis Departemen \\ Keperawatan, Fakultas Kedokteran, Universitas Diponegoro \\ ${ }^{2}$ Mahasiswa Departemen Ilmu Keperawatan, Fakultas Kedokteran, Universitas \\ Diponegoro \\ ${ }^{3}$ Mahasiswa Departemen Ilmu Keperawatan, Fakultas Kedokteran, Universitas \\ Diponegoro \\ megahandriany@fk.undip.ac.id
}

\begin{abstract}
ABSTRAK
Petani tembakau merupakan kelompok berisiko menderita Green Tobacco Sickness. Sedikit peneliti yang meneliti hubungan antara pengetahuan dan persepsi petani tembakau terkait masalah kesehatan yang berhubungan dengan pekerjaan ini. Penelitian ini bertujuan untuk mengetahui hubungan antara pengetahuan dan persepsi tentang masalah kesehatan terkait pekerjaan ini dan perilaku perlindungan diri petani pembakau. Desain penelitian ini adalah deskriptif korelasi dengan 90 petani tembakau sebagai responden yang tiggal dan bekerja sebagai petani tembakau minimal satu tahun di sebuah kecamatan di Kabupaten Kendal. Metode sampling menggunakan simpel random sampling. Peneliti mengembangkan kuesioner berdasarkan Model Promosi Kesehatan Pender. Pengumpulan data menggunakan metode survei dan data dianalisis menggunakan analisis data bivariate dengan metode Chi-Square. Hasil penelitian menunjukkan bahwa terdapat hubungan yang signifikan antara penggunaan alat pelindung diri dengan pengetahuan $(0,000)$ dan persepsi manfaat dari tindakan $(0,003)$, namun tidak terdapat hubungan antara penggunaan alat pelindung diri dengan persepsi kerentanan $(0,066)$, keparahan $(0,086)$, dan hambatan terhadap tindakan $(0,247)$. Penelitian ini merekomendasikan kebutuhan pendidikan kesehatan terkait manfaat penggunaan alat pelindung diri dan beberapa strategi untuk menghilangkan hambatan untuk melaksanakan perilaku.
\end{abstract}

Kata kunci: pengetahuan, perilaku bekerja terlindungi, persepsi, petani tembakau

\section{RELATIONSHIP OF KNOWLEDGE AND PERCEPTION OF WORK HEALTH PROBLEMS AND BEHAVIOR OF USE OF TOBACCO PROTECTIVE TOOLS}

\begin{abstract}
ABTRACT
Tobacco farmer is a risk group for Green Tobacco Sickness. Few studies investigate relationship between knowledge and perception of tobacco farmers regarding health problems related to this job. This study aims to know the relationship between knowledge and perception regarding health problems related to this work and protective behaviors among tobacco farmers. This study was descriptive correlative with 90 tobacco farmers as respondents living and working as tobacco farmers at least one year in a district in Kendal Municipality. The simple random sampling was applied in the study. The researchers developed a questionnaire based on Pender Health Promotion Model. The data collection was conducted by survey method and the data were analyzed using bivariate using Chisquare. The results show that there are significant relationships between knowledge (0.000) and perceived benefits of actions (0.003) and protective working behaviors among respondents. However, there is no relationship between perceived vulnerability (0.066), severity (0.086) and barriers to actions (0.247) and protective working behaviors among them. The study recommends the need of education regarding benefits of protective working behaviors and several strategies to eliminate the barrier to conduct the actions.
\end{abstract}

Keywords: knowledge, perception, protective working behavior, tobacco farmer 


\section{PENDAHULUAN}

Petani tembakau sangat berisiko terkena occupational disease yaitu green tobacco sickness (GTS) sebagai akibat paparan nikotin pada daun tembakau. Kadar nikotin yang ada pada daun tembakau dapat masuk ke dalam tubuh manusia jika daun tembakau dalam keadaan basah (Da Mota E Silva et al., 2018; Fotedar \& Fotedar, 2017; Park, Lim, Lee, \& Yoo, 2018). Nikotin akan masuk ke dalam tubuh manusia melalui kulit dan dibawa oleh aliran darah menuju otak. Nikotin merusak bagian otak, menyebabkan refleks muntah, merangsang saluran pencernaan sehingga terjadi mual dan kram abdominal (Fotedar \& Fotedar, 2017). Meskipun GTS tidak berhubungan dengan mortalitas atau morbiditas, kondisi ini menyebabkan ketidaknyamanan dan kehilangan produktivitas yang signifikan pada petani tembakau (Fotedar \& Fotedar, 2017).

Kejadian GTS pada petani salah satunya dipengaruhi kegagalan petani tembakau dalam penggunaan alat pelindung diri (APD) saat (Da Mota E Silva et al., 2018; Fotedar \& Fotedar, 2017). APD yang harus digunakan antara lain celemek plastik, masker, dan sepatu boots. GTS juga dihubungkan dengan penggantian pakaian basah. Penggunaan pakaian basah secara terus menerus dapat meningkatkan paparan terhadap nikotin dari tembakau matang yang mempunyai nikotin yang lebih larut sehingga lebih mudah terabsorbsi lewat kulit (Saleeon, Siriwong, Maldonado-pérez, \& Robson, 2016).

Saleeon et al menyatakan bahwa beberapa petani selalu menggunakan beberapa bentuk APD untuk melindungi diri dari paparan nikotin ketika bekerja. Beberapa petani meyakini bahwa menggunakan sarung tangan karet atau plastik dapat melindungi dari paparan nikotin (Saleeon et al., 2016), namun tidak menjelaskan hubungan antara pengetahuan dan sikap petani tembakau terhadap perilaku penggunaan APD.

Indonesia merupakan negara dengan petani tembakau keenam terbanyak di dunia pada tahun 2010 dan kelima terbanyak di dunia pada tahun 2012 dimana Indonesia sebagai negara produsen terbanyak pertama di antara negara-negara ASEAN. Jumlah petani tembakau di Indonesia meningkat dari 679.627 pada tahun 2010 menjadi 786.222 pada tahun 2012 (Markus et al., 2015). Penghasil tembakau terbesar di Indonesia yaitu Jawa
Tengah, Jawa Timur, dan Nusa Tenggara Barat (NTB) (Markus et al., 2015; SEATCA, 2013).

Penelitian mengenai GTS belum banyak dilakukan di Indonesia. Beberapa penelitian menyebutkan insiden GTS yaitu di Kabupaten Temanggung sebanyak 63,7\% (Suprapto \& Pradono, 2013) dan di Kabupaten Jember mencapai 66\% (Rokhmah, 2013). Suprapto menyebutkan faktor risiko dari GTS pada petani tembakau meliputi pengalaman bekerja masih sedikit, pemetik daun tembakau letak tengah atas, serta tidak memakai Alat Pelindung Diri (APD) berupa baju lengan panjang. Rokhmah menjelaskan faktor risiko GTS antara lain jenis kelamin dan perilaku pencegahan GTS dari petani itu sendiri. Hasil penelitian tersebut belum meneliti hubungan antara pengetahuan dan persepsi petani tembakau terhadap masalah tersebut. Penelitian ini bertujuan untuk mengetahui hubungan pengetahuan dan persepsi terhadap masalah kesehatan kerja terhadap perilaku penggunaan alat pelindung diri petani tembakau.

\section{Metode}

Penelitian ini merupakan penelitian deskriptif korelasi dengan populasi petani tembakau yang bertempat tinggal dan bekerja di suatu kecamatan di Kabupaten Kendal sebanyak 4.628. Sampel diambil dengan menggunakan metode simple random sampling dan jumlah minimal responden sebanyak 90 orang. Kriteria responden yang diambil adalah bekerja sebagai petani tembakau minimal selama satu tahun. Instrumen dikembangkan berdasarkan variabel dalam Model Promosi Kesehatan Pender (Pender, Murdaugh, \& Parson, 2015). Uji validitas dan reliabilitas dilakukan pada 30 petani tembakau di kelurahan yang berbeda. Item dinyatakan valid ketika $r$ hitung lebih besar dari $r$ tabel $(0,361)$. Item pernyataan yang tidak valid direvisi untuk digunakan dalam pengumpulan data selanjutnya. Penelitian ini telah lolos uji etik dari Komisi Etik Fakultas Kesehatan Masyarakat Universitas Diponegoro. Pengambilan data dilakukan dengan metode survei. Analisis data statistik dengan analisis univariat digunakan untuk menjabarkan secara deskriptif karakteristik, pengetahuan, dan persepsi responden yang meliputi persepsi terhadap kerentanan, keseriusan, manfaat dan 
hambatan. Analisis bivariat untuk data nominal dengan menggunakan Chi-square dengan tingkat signifikansi $(\alpha)=0,05$. Jika nilai $p \geq 0,05$, maka $\mathrm{H}_{0}$ gagal ditolak. Sebaliknya, jika nilai $p<0,05$ maka $\mathrm{H}_{0}$ ditolak.

\section{HASIL}

Hasil dalam penelitian ini meliputi hasil analisis univariat yang terdiri karakteristik responden, pengetahuan, dan persepsi responden. Hasil analisis bivariat juga dijabarkan.

\section{Tabel 1 Distribusi Frekuensi Karakteristik Responden}

\begin{tabular}{|c|c|c|}
\hline \multirow{2}{*}{ Karakteristik Responden } & \multicolumn{2}{|c|}{ Jumlah } \\
\hline & $\mathrm{f}$ & $\%$ \\
\hline \multicolumn{3}{|l|}{ Usia } \\
\hline 20-25 tahun & 4 & 4,44 \\
\hline 26-30 tahun & 3 & 3,33 \\
\hline 31-35 tahun & 11 & 12,2 \\
\hline 36-40 tahun & 7 & 7,78 \\
\hline 41-45 tahun & 12 & 13,3 \\
\hline 46-50 tahun & 23 & 25,6 \\
\hline $51-55$ tahun & 14 & 15,6 \\
\hline 56-60 tahun & 5 & 5,56 \\
\hline 61-65 tahun & 6 & 6,67 \\
\hline 66-70 tahun & 3 & 3,33 \\
\hline 71-75 tahun & 1 & 1,11 \\
\hline 76-80 tahun & 1 & 1,11 \\
\hline \multicolumn{3}{|l|}{ Jenis kelamin } \\
\hline Perempuan & 90 & 100,00 \\
\hline \multicolumn{3}{|l|}{ Pendidikan } \\
\hline Tidak tamat SD & & 44,44 \\
\hline Tamat SD/sederajat & 40 & 25,56 \\
\hline Tamat & 23 & 22,22 \\
\hline SMP/sederajat & 20 & 7,78 \\
\hline Tamat & 7 & \\
\hline \multicolumn{3}{|l|}{ SMA/sederajat } \\
\hline Lama bekerja & & \\
\hline$<1$ tahun & 7 & 7,78 \\
\hline 1-5 tahun & 9 & 10,00 \\
\hline 6-10 tahun & 19 & 21,11 \\
\hline 11-15 tahun & 7 & 7,78 \\
\hline 16-20 tahun & 16 & 17,78 \\
\hline $21-25$ tahun & 8 & 8,89 \\
\hline 26-30 tahun & 11 & 12,22 \\
\hline 31-35 tahun & 2 & 2,22 \\
\hline 36-40 tahun & 9 & 10,00 \\
\hline 41-45 tahun & 1 & 1,11 \\
\hline 46-50 tahun & 1 & 1,11 \\
\hline Total & 90 & 100.0 \\
\hline
\end{tabular}

Tabel 1 menunjukkan bahwa responden terbanyak berusia 46-50 tahun (25,6\%), seluruh responden adalah perempuan, mayoritas tidak tamat SD (44,44\%), dan lama bekerja sebagai petani tembakau terbanyak selama 6-10 tahun $(21,11 \%)$.

Tabel 2 Distribusi Frekuensi Pengetahuan Responden

\begin{tabular}{lcc}
\hline \multicolumn{1}{c}{ Pengetahuan } & \multicolumn{2}{c}{ Jumlah } \\
\cline { 2 - 3 } \multicolumn{1}{c}{ Responden } & $\mathrm{f}$ & $\%$ \\
\hline Kurang baik & 45 & \\
Baik & 45 & 50,0 \\
\hline Total & 90 & 100.0 \\
\hline
\end{tabular}

Tabel 2 menunjukkan bahwa responden yang memiliki pengetahuan kurang baik (50\%) maupun responden yang memiliki pengetahuan baik $(50 \%)$ memiliki persentase yang sama besar.

Tabel 3 Distribusi Frekuensi Persepsi Responden

\begin{tabular}{lcc}
\hline \multirow{2}{*}{ Persepsi Responden } & \multicolumn{2}{c}{ Jumlah } \\
\cline { 2 - 3 } & $\mathrm{f}$ & $\%$ \\
\hline Persepsi kerentanan & & \\
$\quad$ Kurang baik & 45 & 50,0 \\
Baik & 45 & 50,0 \\
Persepsi keseriusan & & \\
$\quad$ Kurang baik & 33 & 36,7 \\
$\quad$ Baik & 57 & 63,3 \\
Persepsi manfaat & & \\
$\quad$ Rendah & 31 & 34,4 \\
$\quad$ Tinggi & 59 & 65,6 \\
Persepsi hambatan & & \\
$\quad$ Rendah & 40 & 44,4 \\
$\quad$ Tinggi & 50 & 55,6 \\
\hline Total & & 100,0 \\
\hline
\end{tabular}

Tabel 3 menunjukkan mayoritas responden menunjukkan persepsi yang baik pada semua variabel persepsi kecuali pada persepsi kerentanan dimana responden mempunyai proporsi yang sama pada persepsi kurang baik dan baik.

Tabel 4 Hubungan antara Pengetahuan dengan Perilaku Kerja Aman
Responden

\begin{tabular}{ccccccc}
\hline & \multicolumn{4}{c}{ Perilaku Kerja Aman } \\
\cline { 2 - 7 } $\begin{array}{c}\text { Pengeta } \\
\text { huan }\end{array}$ & $\begin{array}{c}\text { Kurang } \\
\text { aman }\end{array}$ & Aman & \multicolumn{2}{c}{ Jumlah } \\
\cline { 2 - 7 } & $\mathrm{f}$ & $\%$ & $\mathrm{f}$ & $\%$ & $\mathrm{f}$ & $\%$ \\
\hline Kurang & 24 & 53,3 & 21 & 46,7 & 45 & 100,0 \\
\hline
\end{tabular}




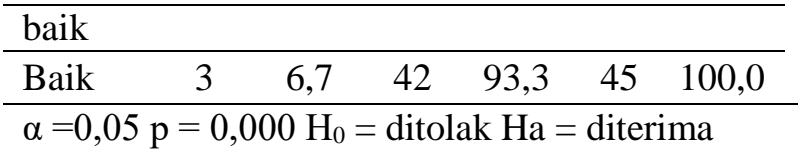

Tabel 4 menunjukkan bahwa responden yang melakukan perilaku kerja kurang aman lebih banyak ditemukan pada responden dengan pengetahuan kurang baik (53,3\%) dibandingkan dengan responden dengan pengetahuan baik $(6,7 \%)$. Uji Chi square menunjukkan nilai $\mathrm{p}=0,000 \quad(<0,05)$ yang berarti terdapat hubungan yang signifikan antara pengetahuan responden dengan perilaku kerja aman.

Tabel 5 Hubungan antara Persepsi Kerentanan dengan Perilaku Kerja Aman Responden

\begin{tabular}{|c|c|c|c|c|c|c|}
\hline \multirow{3}{*}{$\begin{array}{c}\text { Persepsi } \\
\text { Kerentanan }\end{array}$} & \multicolumn{4}{|c|}{ Perilaku Kerja Aman } & \multirow{2}{*}{\multicolumn{2}{|c|}{ Jumlah }} \\
\hline & \multicolumn{2}{|c|}{$\begin{array}{l}\text { Kurang } \\
\text { aman }\end{array}$} & \multicolumn{2}{|c|}{ Aman } & & \\
\hline & $f$ & $\%$ & $f$ & $\%$ & $\mathrm{f}$ & $\%$ \\
\hline $\begin{array}{l}\text { Kurang } \\
\text { baik }\end{array}$ & 18 & 40,0 & 27 & 60,0 & 45 & 100,0 \\
\hline Baik & 9 & 20,0 & 36 & 80,0 & 45 & 100,0 \\
\hline
\end{tabular}

Tabel 5 menunjukkan bahwa responden yang melakukan perilaku kerja kurang aman lebih banyak ditemukan pada responden dengan persepsi kerentanan kurang baik (40\%) dibandingkan dengan responden dengan persepsi kerentanan baik (20\%). Uji Chisquare menunjukkan nilai $\mathrm{p}=0,066(>0,05)$ yang berarti tidak terdapat hubungan antara persepsi kerentanan responden dengan perilaku kerja aman.

Tabel 6 Hubungan antara Persepsi Keseriusan Masalah dengan Perilaku Kerja Aman

\begin{tabular}{lcccccc}
\hline & \multicolumn{3}{c}{ Perilaku Kerja } & \\
Persepsi \\
\cline { 2 - 5 } $\begin{array}{l}\text { Keseriusa } \\
\mathrm{n}\end{array}$ & $\begin{array}{l}\text { Kurang } \\
\text { aman }\end{array}$ & \multicolumn{2}{c}{ Aman } & \\
\cline { 2 - 5 } & $\mathrm{f}$ & $\%$ & $\mathrm{f}$ & $\%$ & $\mathrm{f}$ & $\%$ \\
\hline Kurang & 1 & 42, & 1 & 57, & 3 & 100, \\
baik & 4 & 4 & 9 & 6 & 3 & 0 \\
\hline \multirow{2}{*}{ Baik } & 1 & 22, & 4 & 77, & 5 & 100, \\
& 3 & 8 & 4 & 2 & 7 & 0 \\
\hline $\begin{array}{l}\alpha=0,05 \\
\text { ditolak }\end{array}$ & $\mathrm{p}=0,086$ & $\mathrm{H}_{0}=$ diterima $\mathrm{Ha}=$ \\
\end{tabular}

Tabel 6 menunjukkan bahwa responden yang melakukan perilaku kerja kurang aman lebih banyak ditemukan pada responden dengan persepsi keseriusan kurang baik $(42,4 \%)$ dibandingkan dengan responden dengan persepsi keseriusan baik (22,8\%). Uji Chisquare menunjukkan nilai $\mathrm{p}=0,60 \quad(>0,05)$ yang berarti tidak terdapat hubungan antara persepsi keseriusan responden dengan perilaku kerja aman.

Tabel 7 Hubungan antara Persepsi Manfaat dengan Perilaku Kerja Aman

\begin{tabular}{|c|c|c|c|c|c|c|}
\hline \multirow{3}{*}{$\begin{array}{l}\text { Persepsi } \\
\text { Manfaat }\end{array}$} & \multicolumn{4}{|c|}{ Perilaku Kerja Aman } & \multirow{2}{*}{\multicolumn{2}{|c|}{ Jumlah }} \\
\hline & \multicolumn{2}{|c|}{$\begin{array}{c}\text { Kurang } \\
\text { aman }\end{array}$} & \multicolumn{2}{|c|}{ Aman } & & \\
\hline & $\mathrm{f}$ & $\%$ & $\mathrm{f}$ & $\%$ & $\mathrm{f}$ & $\%$ \\
\hline Rendah & 16 & 51,6 & 15 & 48,4 & 31 & 100,0 \\
\hline Tinggi & 11 & 18,6 & 48 & 81,4 & 59 & 100,0 \\
\hline
\end{tabular}

Tabel 7 menunjukkan bahwa responden yang melakukan perilaku kerja kurang aman lebih banyak ditemukan pada responden dengan persepsi manfaat rendah $(51,6 \%)$ dibandingkan dengan responden dengan persepsi manfaat tinggi $(18,6 \%)$. Uji Chisquare menunjukkan nilai $\mathrm{p}=0,002 \quad(<0,05)$ yang berarti terdapat hubungan yang signifikan antara persepsi manfaat responden dengan perilaku kerja aman.

Tabel 8 Hubungan antara Persepsi Hambatan dengan Perilaku Kerja Aman

\begin{tabular}{lcccccc}
\hline \multirow{2}{*}{$\begin{array}{l}\text { Persepsi } \\
\text { Hambatan }\end{array}$} & \multicolumn{3}{c}{ Perilaku Kerja Aman } & \multicolumn{2}{c}{$\begin{array}{c}\text { Kurang } \\
\text { aman }\end{array}$} & \multicolumn{2}{c}{ Aman } & \multicolumn{2}{l}{ Jumlah } \\
\cline { 2 - 6 } & $\mathrm{f}$ & $\%$ & $\mathrm{f}$ & $\%$ & $\mathrm{f}$ & $\%$ \\
\hline Rendah & 9 & 22,5 & 31 & 77,5 & 40 & 100,0 \\
\hline Tinggi & 18 & 36,0 & 32 & 64,0 & 50 & 100,0 \\
\hline$\alpha=0,05 \quad \mathrm{p}=0,247$ & $\mathrm{H} 0=$ diterima Ha = ditolak
\end{tabular}

Tabel 8 menunjukkan bahwa responden yang melakukan perilaku kerja kurang aman lebih banyak ditemukan pada responden dengan persepsi hambatan tinggi (36\%) dibandingkan dengan responden dengan persepsi hambatan rendah (22,5\%). Uji Chi-square menunjukkan nilai $\mathrm{p}=0,247 \quad(>0,05)$ yang berarti tidak terdapat hubungan antara persepsi hambatan dengan perilaku kerja aman responden. 


\section{PEMBAHASAN}

Hasil penelitian ini menunjukkan bahwa responden dengan pengetahuan baik maupun kurang baik mengenai perilaku kerja aman memiliki jumlah yang sama yaitu $50 \%$. Pengetahuan yang dimaksud adalah pemahaman responden melalui pertanyaan yang diajukan mengenai perilaku kerja aman di pertanian tembakau yang meliputi penggunaan alat pelindung diri (APD) dan kebersihan diri (personal hygiene). Kondisi ini berbeda dengan penelitian Rokhmah yang menunjukkan bahwa sebagian besar $(96,6 \%)$ petani tembakau mempunyai pengetahuan yang rendah mengenai GTS (Rokhmah, 2013).

Hasil penelitian juga menunjukkan bahwa pengetahuan responden berhubungan dengan pendidikan terakhir responden, dimana pendidikan terakhir responden pada penelitian ini yaitu tidak tamat SD (44,4\%) sehingga masih terdapat banyak responden yang kurang mengetahui perilaku kerja aman. Menurut Notoatmojo dalam Putri tahun 2014, pendidikan merupakan salah satu faktor pada tenaga kerja yang dapat mempengaruhi perilaku. Pendidikan juga akan mempengaruhi tenaga kerja dalam upaya mencegah penyakit dan meningkatkan kemampuannya dalam memelihara kesehatan (Putri \& Denny, 2014). Hal tersebut menjelaskan bahwa pendidikan seseorang akan berpengaruh terhadap pengetahuan seseorang yang akan berpengaruh terhadap perilaku seseorang.

Hal ini juga sesuai dengan penelitian Fauziah dan Darmasetiawan yang menyatakan bahwa petani tembakau memiliki tingkat pendidikan yang rendah. Tingkat pendidikan seseorang mempengaruhi tingkat pengetahuan termasuk dalam masalah kesehatan dengan rendahnya tingkat pendidikan petani tembakau, maka rendah pula pengetahuan petani dalam mencegah gejala GTS (Darmasetiawan \& Wicaksono, 2012; Fauziyah, 2010).

Persepsi hambatan responden masih tinggi sehingga dapat diinterpretasikan bahwa penggunaan APD pada petani tembakau masih mengalami banyak hambatan terkait budaya atau kebiasaan, pemahaman terhadap fungsi APD, dan ketersediaan APD. Pemberian APD secara cuma-cuma diyakini para pekerja dapat meningkatkan pemakaian APD (Fekadu et al., 2018). Hasil penelitian ini kurang mengungkap alasan petani tembakau tidak menggunakan APD yang disebabkan oleh kondisi tidak nyaman akibat berkeringat dan panas. Berkeringat menyebabkan petani tembakau tidak menggunakan pakaian luar yang lengan panjang dan yang anti air (Walton, LePrevost, Linnan, Sanchez-Birkhead, \& Mooney, 2017).

Hasil penelitian ini menunjukkan bahwa pengetahuan memiliki hubungan yang signifikan dengan perilaku kerja aman. Hal ini sesuai Green yang menyatakan bahwa perilaku seseorang dipengaruhi oleh tiga faktor utama, salah satunya adalah predisposing factors. Pengetahuan merupakan salah satu faktor yang termasuk dalam predisposisi karena dapat mempermudah atau mendasari terjadinya suatu perilaku tertentu. Pengetahuan merupakan domain yang sangat penting dalam membentuk tindakan seseorang. Pengetahuan yang positif akan berdampak pada perilaku yang positif juga (Green \& Kreuter, 2005).

Hasil penelitian juga menunjukkan adanya hubungan yang signifikan antara persepsi terhadap manfaat berhubungan secara signifikan terhadap perilaku petani dalam menggunakan APD. Persepsi manfaat suatu perilaku merupakan perwakilan mental yang positif atau konsekuensi yang mendorong suatu perilaku. Seorang individu berharap untuk terlibat dalam suatu perilaku tertentu untuk memperoleh manfaat yang telah diperkirakan (Pender et al., 2015). Pada penelitian ini, petani menggunakan APD untuk memperkecil paparan pestisida atau zat kimia lainnya sehingga terhindar dari masalah kesehatan yang terkait. Manfaat yang dirasakan oleh petani ini tergolong pada manfaat intrinsik yang meliputi peningkatan kewaspadaan (Pender et al., 2015).

Hasil korelasi yang kontradiktif terjadi pada variabel persepsi lainnya yaitu persepsi terhadap kerentanan, keseriusan, hambatan. Hasil penelitian menunjukkan tidak adanya hubungan antara ketiga variabel tersebut dengan perilaku penggunaan APD. Hal ini tidak sesuai dengan asumsi Pender yang menyatakan bahwa ketika kesiapan untuk berperilaku rendah dan hambatan tinggi, maka perilaku cenderung tidak terjadi (Pender et al., 2015). Kondisi ini berarti bahwa hambatan yang dapat meliputi ketersediaan informasi dan ketrampilan kesehatan dan keselamatan kerja; harga; fasilitas; dan ketidakpraktisan penggunaan APD tidak mempengaruhi perilaku petani dalam menggunakan APD. Selain itu, persepsi petani terhadap kerentanan dan keseriusan akan terkena dampak zat kimia 
yang meliputi pestisida dan nikotin dalam tanaman tembakau tidak berdampak terhadap penggunaan APD. Hal ini juga kontradiktif terhadap hasil penelitian ini yang menjelaskan bahwa petani akan menggunakan APD karena manfaat yang diperoleh yaitu terhindar dari masalah kesehatan yang akan terjadi. Kondisi ini dimungkinkan karena petani berasumi bahwa masalah kesehatan yang mungkin muncul akibat pestisida atau zat kimia lain dalam tembakau dianggap tidak terlalu menyebabkan masalah kesehatan yang serius.

Hasil penelitian yang kontradiktif juga mungkin terjadi akibat keterbatasan penelitian dimana instrumen dikembangkan sendiri oleh peneliti dan tidak menggunakan kuesioner yang telah baku. Pengembangan kuesioner sebaiknya menggunakan 8 (delapan) langkah menurut DeVellis yang meliputi (1) menentukan konsep yang akan diukur; (2) memilih item-item yang merefleksikan tujuan instrumen; (3) menentukan format pengukuran terhadap respon responden; (4) telaah item oleh ahli; (5) mempertimbangkan inklusi validasi item; (6) mengimplementasikan item pada sampel; (7) mengevaluasi item; dan (8) mengoptimalkan panjang skala/reliabilitas (DeVellis, 2017).

\section{SIMPULAN DAN SARAN}

Hasil penelitian menunjukkan bahwa terdapat hubungan yang signifikan antara pengetahuan responden dengan perilaku kerja aman dan antara persepsi manfaat responden dengan perilaku kerja aman. Di sisi lain, tidak terdapat hubungan antara persepsi kerentanan responden dengan perilaku kerja aman, antara persepsi keseriusan responden dengan perilaku kerja aman, dan antara persepsi hambatan dengan perilaku kerja aman responden.

Hasil penelitian ini merekomendasikan tenaga kesehatan untuk menekankan pada pengetahuan mengenai GTS dan manfaat perilaku kerja aman. Peneliti belum menerapkan secara detail langkah tersebut seperti penentuan konsep yang diukur sebaiknya menggunakan metode concept analysis sehingga dapat konsep yang akan diukur benar-benar dapat dibedakan dengan konsep lainnya.

\section{DAFTAR PUSTAKA}

Da Mota E Silva, M. S., Da Glória Da Costa Carvalho, M., Moreira, J. C., De Oliveira Barreto, E., De Farias, K. F.,
Nascimento, C. A., ... Ribeiro, F. L. (2018). Green Tobacco Sickness among Brazilian farm workers and genetic polymorphisms. BMC Research Notes, 11(1), 1-5. doi: 10.1186/s13104-018$3135-\mathrm{x}$

Darmasetiawan, N., \& Wicaksono, I. A. (2012). Pengaruh faktor internal petani terhadap peningkatan mutu tembakau di Desa Pacekelan Kecamatan Purworejo Kabupaten Purworejo. Surya Agritama, I(1), 48-58.

DeVellis, R. F. (2017). Scale development: theory and applications (4th ed.). London: SAGE.

Fauziyah, E. (2010). Pengaruh perilaku risiko produksi petani terhadap alokasi input usaha tani tembakau: pendekatan fungsi produksi frontir stokastik. Institut Pertanian Bogo.

Fekadu, F., Beyene, T. J., Beyi, A. F., Edao, B. M., Tufa, T. B., Woldemariyam, F. T., \& Gutema, F. D. (2018). Risk perceptions and protective behaviors toward Bovine Tuberculosis among abattoir and butcher workers in Ethiopia. Frontiers in Veterinary Science, 5(July), 1-9. doi: 10.3389/fvets.2018.00169

Fotedar, S., \& Fotedar, V. (2017). Green Tobacco Sickness: A Brief Review. Indian Journal of Occupational and Environmental Medicine, 21(3), 101104. doi: 10.4103/ijoem.IJOEM_160_17

Green, L. W., \& Kreuter, M. W. (2005). The PRECEDE-PROCEED model of health program planning and evaluation. In Health Promotion Planning: An Educational and Ecological Approach (4ht ed.). NY: McGraw-Hill.

Markus, S., Sapartinah, T., Kurniawan, D. W., Jayadi, A., Ahsan, A., Malik, A., ... Wiyono, N. (2015). Petani tembakau di Indonesia: sebuah paradoks kehidupan. Indonesian Institute for Social Development.

Park, S. J., Lim, H. S., Lee, K., \& Yoo, S. J. (2018). Green Tobacco Sickness among tobacco harvesters in a Korean village. Safety and Health at Work, 9(1), 71-74. doi: 10.1016/j.shaw.2017.06.007

Pender, N. J., Murdaugh, C. L., \& Parson, M. A. (2015). Health promotion in nursing practice (7th ed.). NY: Pearson.

Putri, K. D. S., \& Denny, Y. (2014). Analisis faktor yang berhubungan dengan 
kepatuhan menggunakan alat pelindung diri. The Indonesian Journal of Occupational Safety, Health and Environment, 1(1), 24-36.

Rokhmah, D. (2013). Analisis faktor risiko

Green Tobacco Sickness (GTS) dan metode penangannya pada petani tembakau. Jember. Retrieved from https://repository.unej.ac.id/bitstream/han dle/123456789/58903/dewi_pemula_205. pdf?sequence $=1$

Saleeon, T., Siriwong, W., Maldonado-pérez, H. L., \& Robson, M. G. (2016). Green tobacco sickness and protective behavior among Thai traditional tobacco farmers in Northern Thailand. J Health Res, 30(4), 289-295. doi: 10.14456/jhr.2016.39
SEATCA. (2013). Status of tobacco farming in the Asean region.

Suprapto, S., \& Pradono, J. (2013). Faktor risiko "Green Tobacco Sickness" (GTS) pada petani pemetik daun tembakau di Desa Bansari, Kabupaten Temanggung, Jawa Tengah. Jurnal Ekologi Kesehatan, 2(3), 275-281. doi: 10.1109/TIP.2017.2751142

Walton, A. M. L., LePrevost, C. E., Linnan, L., Sanchez-Birkhead, A., \& Mooney, K. (2017). Benefits, facilitators, barriers, and strategies to improve pesticide protective behaviors: Insights from farmworkers in North Carolina tobacco fields. International Journal of Environmental Research and Public Health, 14(7), 1-13. doi: 10.3390/ijerph14070677 